\title{
IMPLEMENTASI PEMBELAJARAN KALOR MELALUI PENDEKATAN SAINTIFIK DENGAN MODEL PEMBELAJARAN DISCOVERY LEARNING MATA PELAJARAN IPA SISWA MTS
}

\author{
BEKTI NURHAMIDA \\ MTs Negeri 2 Sleman \\ e-mail: bektinurhamida@gmail.com
}

\begin{abstract}
ABSTRAK
Penelitian ini bertujuan untuk: mengetahui peningkatan hasil belajar IPA dengan menggunakan model Discovery learning. Penelitian ini merupakan penelitian eksperimen dengan menggunakan kelompok eksperimen dan satu kelompok kontrol. Populasi penelitian mencakup seluruh peserta didik kelas VII MTs Negeri 2 Sleman dan sampel peserta didik kelas VIIE. Instrumen penelitian yang digunakan meliputi tes prestasi belajar IPA yaitu pretest dan postest. Analisis data untuk mengetahui peningkatan pembelajaran dengan model Discovery learning dilakukan dengan melihat peningkatan nilai rata-rata dan nilai ketuntasan klasikal. Penerapan model pembelajaran Discovery learning meningkatkan hasil belajar siswa. Hal ini dibuktikan dari peningkatan ketuntasan klasikal dan rata-rata hasil belajar siswa. Ketuntasan klasikal siswa, meningkat sebesar $53,12 \%$, yaitu dari $28,12 \%$ menjadi $81,25 \%$. Sedangkan rata-rata hasil belajar siswa meningkat sebesar 9 poin yaitu dari 67 menjadi 76
\end{abstract}

Kata Kunci: Discovery learning, prestasi belajar

\section{ABSTRACT}

This study aims to: determine the increase in science learning outcomes by using the Discovery learning model. This research is an experimental study using an experimental group and a control group. The research population includes all students of class VII MTs Negeri 2 Sleman and a sample of class VIIE students. The research instrument used included science learning achievement tests, namely pretest and posttest. Data analysis to determine the increase in learning with the Discovery learning model was carried out by looking at the increase in the average value and classical completeness value. The application of the Discovery learning learning model improves student learning outcomes. This is evidenced by the increase in classical completeness and the average student learning outcomes. The classical mastery of students increased by $53.12 \%$, from $28.12 \%$ to $81.25 \%$. While the average student learning outcomes increased by 9 points, namely from 67 to 76

Keywords: Discovery learning, learning achievement

\section{PENDAHULUAN}

Pendidikan menurut Undang-Undang Nomor 20 Tahun 2003 tentang Sistem Pendidikan Nasional, Pasal 1 angka 1 menyatakan bahwa pendidikan merupakan usaha sadar dan terencana untuk mewujudkan suasana belajar dan proses pembelajaran agar peserta didik secara aktif mengembangkan potensi dirinya untuk memiliki kekuatan spiritual keagamaan, pengendalian diri, kepribadian, kecerdasan, akhlak mulia, serta keterampilan yang diperlukan dirinya, masyarakat, bangsa dan Negara (Kemendikbud, 2003:2)

Hal ini sesuai dengan Standar Proses pembelajaran dalam peraturan mentri Pendidikan dan Kebudayaan No 65 tahun 2013. Peraturan tersebut menyatakan bahwa proses pembelajaran pada satuan pendidikan diselenggarakan secara interaktif, inspiratif, menyenangkan, menantang, memotivasi peserta didik untuk berpartisipasi aktif, serta memberikan ruang yang cukup bagi prakarsa, kreativitas, dan kemandirian sesuai dengan bakat, minat, dan perkembangan fisik serta psikologis peserta didik. Dalam hal ini pembelajaran IPA dalam kurikulum 2013 menggunakan prinsip yang: (1) berpusat pada peserta didik, (2) mengembangkan kreativitas peserta didik, (3) menciptakan kondisi menyenangkan dan menantang, (4) bermuatan nilai, etika, estetika, logika, dan kinestetika, dan (5) menyediakan 
pengalaman belajar yang beragam melalui penerapan berbagai strategi dan metode pembelajaran yang menyenangkan, kontekstual, efektif, efisien, dan bermakna (Nuh, 2013:1). Sehingga pembelajaran yang bermakna dapat dilakukan dengan menggunakan metode ilmiah yaitu suatu metode untuk melakukan penyelidikan ilmiah yang menggunakan ketrampilan proses sains. Pembelajaran sains sebaiknya menekankan pada proses, peserta didik lebih aktif selama pembelajaran untuk membangun pengetahuannya melalui serangkaian kegiatan agar pembelajaran menjadi lebih bermakna bagi peserta didik.

Sesuai dengan hakikat IPA yang meliputi empat unsur utama yaitu: (1) sikap: rasa ingin tahu tentang benda, fenomena alam, makhluk hidup, serta hubungan sebab akibat yang menimbulkan masalah baru yang dapat dipecahkan melalui prosedur yang benar; IPA bersifat open ended; (2) proses: prosedur pemecahan masalah melalui metode ilmiah; metode ilmiah meliputi penyusunan hipotesis, perancangan eksperimen atau percobaan, evaluasi, pengukuran, dan penarikan kesimpulan; (3) produk: berupa fakta, prinsip, teori, dan hukum; dan (4) aplikasi: penerapan metode ilmiah dan konsep IPA dalam kehidupan sehari-hari (kemendikbud, 2013:213).

Menurut Prasetyo (2004:27), hakekat sains dipandang sebagai suatu proses dan sekaligus produk, sehingga dalam pembelajaran sains harus dijadikan dalam memilih strategi atau metode mengajar sehingga proses belajar mengajar dapat berlangsung efektif dan efisien. Pembelajaran sains merupakan pemberian pengalaman belajar secara langsung melalui penggunaan dan pengembangan keterampilan proses dan sikap ilmiah, Kemendikbud (2013: 212).

Slavin (2011: 47) menyatakan bahwa pengajaraan efektif mengandung empat hal yaitu (1) mutu pengajaran, (2) tingkat pengajaran yang tepat, (3) insentif dan (4) waktu. Menurut Slameto (2013: 95) mengatakan bahwa mengajar yang efektif perlu mempertimbangkan halhal berikut, (1) Guru harus menguasai bahan pelajaran, (2) cinta kepada yang diajarkan, (3) pengalaman pribadi dan pengetahuan yang telah dimiliki peserta didik, (4)variasi metode, (5) guru harus selalu memberikan pengetahuan yang aktual dan dipersiapkan sebaik-baiknya dan (6) harus mampu menimbulkan semangat belajar pada peserta didik

Belajar merupakan suatu proses usaha yang dilakukan seseorang untuk memperoleh suatu perubahan tingkah laku yang baru secara keseluruhan, sebagai hasil pengalamannya sendiri dalam interaksi dengan lingkungannya (Slameto, 2003: 2).

Untuk di MTs N 2 Sleman sendiri, dalam proses belajar mengajar sains peserta didik sudah dipancing untuk melakukan kegiatan tersebut, tetapi belum dapat berjalan sebagaimana yang diharapkan. Peserta didik cenderung masih menunggu materi yang disampaikan oleh gurunya.

Dalam pembelajaran IPA, peserta didik diusahakan untuk dapat menggunakan ketrampilan berupa metode ilmiah, sehingga ilmu yang didapat dapat mengena dan bermakna. Tetapi penguasaan metode ilmiah, belum biasa dipakai dalam pembelajaran, hal ini karena biasanya guru akan merasa repot untuk menerapkan metode ilmiah, dengan mempersiapkan langkah-langkahnya. Alokasi waktu juga menjadi alasan untuk menerapkan metode ilmiah, karena antara peserta didik tidak sama kemampuannya sehingga perlu waktu yang lama dalam proses belajar mengajar. Guru tidak mau repot, yang penting semua materi dapat disampaikan semua kepada peserta didik.

Berdasarkan beberapa pendapat diatas dan sejalan dengan rumusan masalah yaitu siswa kurang antusias dalam mengikuti pembelajaran dikarenakan model mengajar yang digunakan oleh guru kebanyakan hanya ceramah, maka penulis akan memperbaiki pembelajaran yang dapat mengajak siswa untuk menemukan sendiri jawabnya dan membuat aktif siswa dalam pembelajaran, siswa merasa senang dan antusias dalam mengikuti pembelajaran yang di tuangkan dalam Best Practice dengan judul Implementasi pembelajaran kalor melalui pendekatan saintifik dengan menggunakan model pembelajaran Discovery Learning mata pelajaran IPA. 


\section{METODE PENELITIAN}

Subjek penelitian adalah Peserta didik kelas VII E Semester Ganjil Tahun 2015 di MTs Negeri 2 Sleman sebanyak 32 orang. Penulis mengambil judul Implementasi pembelajaran kalor melalui pendekatan saintifik dengan menggunakan model pembelajaran Discovery Learning mata pelajaran IPA. Waktu yang digunakan pada hari Rabu tanggal 18 maret $2015-$ Rabu tanggal 8 April 2015, bertempat di kelas VII E dan laboratorium IPA MTs Negeri 2 Sleman.

Metode yang digunakan adalah metode eksperimen dengan teknik pengambilan data instrumen untuk melihat hasil belajar siswa dengan menggunakan tes tulis pilihan ganda, yang dilakukan sebelum pembelajaran atau melakukan pretest dan dilakukan setelah pembelajaran atau postest. Analisis data untuk mengetahui peningkatan hasil belajar dengan pembelajaran model Discovery learning dilakukan dengan melihat peningkatan nilai rata-rata dan nilai ketuntasan klasikal

Selanjutnya penulis menyusun perangkat pembelajaran berupa: Rencana Pelaksanaan Pembelajaran (RPP), bahan ajar, Lembar Kerja Siswa (LKS) dan soal.

\section{HASIL DAN PEMBAHASAN}

Dalam penelitian ini dibuat perangkat pembelajaran IPA untuk kelancaran kegiatan belajar mengajar, yaitu pembelajaran model Discovery Learning. Komponen- komponen perangkat pembelajaran yaitu Silabus, RPP, LKS dan Instrumen penilaian.

Hasil

Penerapan model pembelajaran Discovery Learning juga meningkatkan kemampuan siswa dalam memecahkan masalah (problem solving). Discovery Learning yang diterapkan dengan menyajikan Lembar kerja Siswa mampu mendorong siswa merumuskan pemecahan masalah dan menemukan sendiri jawabannya, dalam proses pembelajaran anak-anak merasa cocok, senang dan antusias untuk mengikutinya. Sesuai dengan Prasetyo (2004: 3.19), kegiatan proses belajar mengajar discovery learning melibatkan proses mental mereka untuk mengamati, menduga, menjelaskan, dan menarik kesimpulan. Pembelajaran dalam pembelajaran ini sesuai dengan prinsip metode ilmiah, sehingga sesuai untuk meningkatkan penguasaan metode ilmiah peserta didik. Pembelajaran model discovery learning dapat dilihat dari kegiatan belajar mengajar peserta didik yang merasa senang untuk belajar IPA. Menurut Kemendikbud (2013: 266), menyatakan bahwa salah satu keunggulan pembelajaran discovery learning adalah menimbulkan rasa senang pada siswa, karena tumbuhnya rasa menyelidiki dan berhasil.

Proses kegiatan belajar mengajar dalam penelitian ini, peserta didik antusias dan aktif untuk mengikuti pelajaran, karena mereka bisa menunjukkan kemampuannya untuk kegiatan belajarnya sendiri dengan melibatkan akalnya dan motivasi sendiri. Peserta didik dapat mengeksplor kemampuannya bersama teman-teman sekelompoknya, sehingga dapat menemukan sendiri jawaban yang diinginkan. Peserta didik kelihatan sangat aktif, antusias dan mengikutinya sesuai dengan langkah dalam LKS

Berdasarkan hasil Belajar siswa yang telah dilaksanakan, dapat diketahui hasil belajar siswa pada Tabel 1 sebagai berikut.

Tabel 1. Hasil belajar Siswa kelas VIIE

\begin{tabular}{cccc}
\hline No & Kode Anak & nilai & Ketuntasan \\
\hline 1 & B 001 & 50 & tidak tuntas \\
2 & B 002 & 81 & tuntas \\
3 & B 003 & 100 & tuntas \\
4 & B 004 & 75 & tuntas \\
5 & B 005 & 75 & tidak tuntas \\
6 & B 006 & 63 & tuntas \\
7 & B 007 & 75 & tuntas
\end{tabular}




\begin{tabular}{cccc}
9 & B 009 & 75 & tuntas \\
10 & B 010 & 81 & tuntas \\
11 & B 011 & 88 & tuntas \\
12 & B 012 & 88 & tuntas \\
13 & B 013 & 81 & tuntas \\
14 & B 014 & 69 & tuntas \\
15 & B 015 & 81 & tuntas \\
16 & B 016 & 81 & tuntas \\
17 & B 017 & 75 & tuntas \\
18 & B 018 & 81 & tuntas \\
19 & B 019 & 94 & tuntas \\
20 & B 020 & 75 & tidak tuntas \\
21 & B 021 & 69 & tuntas \\
22 & B 022 & 75 & tidak tuntas \\
23 & B 023 & 63 & tuntas \\
24 & B 024 & 75 & tuntas \\
25 & B 025 & 75 & tidak tuntas \\
26 & B 026 & 69 & tuntas \\
27 & B 027 & 81 & tuntas \\
28 & B 028 & 75 & tuntas \\
29 & B 029 & 75 & tuntas \\
30 & B 030 & 78 & tuntas \\
31 & B 031 & 81 & tuntas \\
32 & B 032 & 84 & \\
& Jumlah & 2462 & \\
\hline
\end{tabular}

Berdasarkan Tabel 1, maka dapat dihitung ketuntasan klasikal dan rata-rata siswa sebagai berikut.

1. Ketuntasan klasikal

Untuk menghitung ketuntasan klasikal siswa, maka dapat menggunakan rumus sebagai berikut.

$$
\begin{aligned}
K K= & \frac{\text { Jumlah siswa yang tuntas }}{\text { Jumlah seluruh siswa }} \times 100 \% \\
& =\frac{26}{32} \times 100 \% \\
& =81,25 \%
\end{aligned}
$$

Sehingga diperoleh ketuntasan klasikal siswa sebesar $81,25 \%$, yang artinya ketuntasan klasikal siswa meningkat sebesar $53,13 \%$ dari ketuntasan awal siswa.

2. Rata-rata

Berdasarkan tabel di atas, maka dapat dihitung rata-rata siswa menggunakan rumus berikut.

$$
\begin{aligned}
M & =\frac{\sum f x}{N} \\
& =\frac{2462}{32} \\
& =76,95
\end{aligned}
$$

Dengan demikian dapat diketahui rata-rata siswa sebesar 76,95. Rata-rata siswa meningkat sebesar 9,84 poin dari rata-rata awal. Peningkatan ketuntasan klasikal dan rata-rata siswa menunjukkan bahwa penerapan Pendekatan Saintifik dengan model Pembelajaran Discovery Learning sangat efektif dalam meningkatkan hasil belajar siswa. Untuk lebih jelas mengenai peningkatan ketuntasan klasikal dan rata-rata siswa, dapat dilihat pada diagram Gambar 1 berikut. 


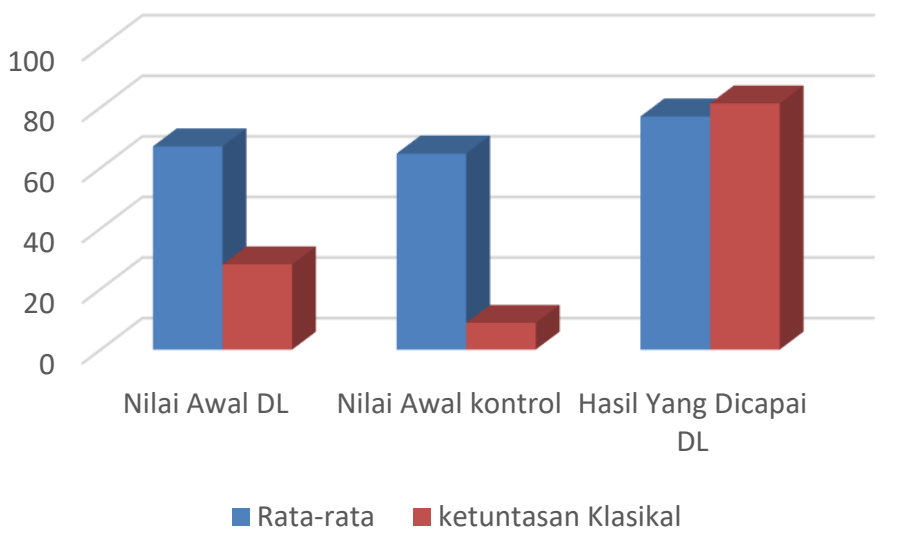

Gambar 1. Ketuntasan Klasikal

\section{Pembahasan}

Berdasarkan hasil analisis data, diperoleh bahwa pembelajaran dengan model discovery learning dapat meningkatkan hasil belajar peserta didik. Sejalan dengan Setyawati (2018) pembelajaran menggunakan model pembelajaran discovery learning dengan pendekatan saintifik dapat meningkatkan hasil belajar peserta didik yang ditunjukkan dengan adanya peningkatan hasil belajar.

Menurut Eko Wahyudi (2015), Pembelajaran Discovery Learning dalam pembelajaran IPA akan meningkatkan aktifitas siswa dalam belajar baik secara individu maupun secara kelompok. Meningkatnya aktifitas siswa dalam pembelajaran membuat siswa semakin bersemangat dalam belajar dan akan meningkatkan hasil belajar siswa. Bruner dan rekan rekannya memberikan dukungan teoritik tentang discovery learning (Arends, 2008: 48), ini sebuah model pengajaran yang menekankan pentingnya membantu peserta didik untuk memahami struktur atau ide-ide kunci suatu disiplin ilmu, kebutuhan akan keterlibatan aktif peserta didik dalam proses belajar, dan keyakinan bahwa pembelajaran sejati terjadi melalui personal discovery ( penemuaan pribadi). Tujuan pendidikan bukan hanya untuk memperbesar dasar pengetahuan peserta didik, tetapi juga untuk menciptakan berbagai kemungkinan untuk invention (penciptaan) dan discovery (penemuan).

Menurut Widiadnyana (2014), terdapat perbedaan pemahaman konsep IPA secara signifikan antara siswa yang belajar menggunakan model discovery learning dengan siswa yang belajar menggunakan model pengajaran langsung $(\mathrm{F}=7,774 ; \mathrm{p}<0,05)$. Menurut Indarti, Sri (2019), model pembelajaran Discovery Learning berbasis pendekatan saintifik dapat meningkatkan aktivitas dan hasil belajar peserta didik pada pembelajaran IPA. Hasil penelitian Khamidah dkk(2019) menunjukkan bahwa ada pengaruh yang signifikan dari penerapan bahan ajar digital interaktif dengan model discovery learning terhadap prestasi belajar siswa. Dengan demikian, penggunaan bahan ajar digital interaktif dengan model discovery learning bisa digunakan oleh guru untuk mengakomodasi kemampuan kognitif siswa sehingga prestasi belajar siswa dapat meningkat. Pembelajaran dilakukan dengan tiga siklus dan setiap pembelajaran, dilakukan postes. Nilai rata-rata pre-tes siklus I : 29,17 ; siklus II : 41,11; dan siklus III : 33,50. Nilai rata-rata postes siklus I : 71,25; siklus II : 74,44; dan siklus III : 77,04. Persentase peningkatan N-gain hasil belajar pada siklus I: 59\%; siklus II : 57\%; dan siklus III : 65\%, masing-masing pada kategori sedang. Berdasarkan hasil penelitian Simanjuntak dkk(2019) dapat disimpulkan bahwa ada peningkatan hasil belajar IPA siswa SMP dengan menggunakan model discovery learning.

Sesuai dengan pendapat diatas, berdasarkan data analisis menunjukkan bahwa nilai ratarata pretest pada kelompok discovery learning sebesar 67,1 dan kelompok kontrol 60. Rata-rata nilai posttest kelompok discovery learning, dan kontrol masing-masing adalah 76,9 dan 73. Pada saat pretest masing-masing untuk kelompok discovery learning dan kelompok kontrol yang tuntas adalah $28,12 \%$ dan $8,82 \%$. Setelah treatment, terjadi peningkatan ketuntasan pada 
kelompok discovery learning dan kelompok kontrol masing-masing adalah 53,12\%, dan $47,05 \%$.

Dengan demikian dapat diketahui nilai rata-rata siswa sebesar 76,9. Rata-rata siswa meningkat sebesar 9,8 poin dari rata-rata awal. Sedangkan untuk kelas pembandingnya peningkatannya sebesar 8 poin. Peningkatan ketuntasan klasikal dan rata-rata siswa menunjukkan bahwa penerapan Pendekatan Saintifik dengan model Pembelajaran Discovery Learning sangat efektif dalam meningkatkan hasil belajar siswa.

Menurut Carin \& Sund (1980: 74), discovery merupakan proses mental untuk mengasimilasi konsep dan prinsip, belajar bagaimana menggunakan pikiran untuk menemukan. Proses penemuan dengan langkah-langkah: (1) observing yaitu pengamatan, (2) classifying yaitu mengelompokkan, (3) measuring yaitu dengan pengukuran, (4) predicting dengan memprediksi, (5) describing (mendeskripsikan), dan (6) inferring (menyimpulkan)

Hasil prestasi belajar dengan pembelajaran discovery learning menunjukkan peningkatan dilihat dari pretest dan postest peserta didik, dilihat dari nilai rata-rata meningkat 9 point, sedangkan dari ketuntasan klasikal terjadi peningkatan 53,12\%.

Peserta didik mungkin mereka cocok dan senang dengan menggunakan model pembelajaran ini. Menurut pendapat Slavin (2011: 8), menyatakan bahwa peserta didik didorong untuk belajar sendiri melalui keterlibatan aktif dengan konsep-konsep dan prinsipprinsip, dan guru mendorong peserta didik memperoleh pengalaman dan melakukan eksperimen yang memungkinkan mereka menemukan sendiri prinsip.

Proses pembelajaran discovery learning ini menyebabkan anak-anak merasa cocok, senang dan antusias untuk mengikutinya. Antusiasme dalam pembelajaran ini dapat meningkatkan penguasaan metode ilmiah yang dimiliki peserta didik. Sesuai dengan Prasetyo (2004: 3.19), kegiatan proses belajar mengajar discovery learning melibatkan proses mental mereka untuk mengamati, menduga, menjelaskan, dan menarik kesimpulan

Pembelajaran dalam pembelajaran ini sesuai dengan prinsip metode ilmiah, sehingga sesuai untuk meningkatkan penguasaan metode ilmiah peserta didik. Pembelajaran model discovery learning dapat dilihat dari kegiatan belajar mengajar peserta didik yang merasa senang untuk belajar IPA. Menurut Kemendikbud (2013: 266), menyatakan bahwa salah satu keunggulan pembelajaran discovery learning adalah menimbulkan rasa senang pada siswa, karena tumbuhnya rasa menyelidiki dan berhasil.

Proses kegiatan belajar mengajar ini, peserta didik antusias dan aktif untuk mengikuti pelajaran, karena mereka bisa menunjukkan kemampuannya untuk kegiatan belajarnya sendiri dengan melibatkan akalnya dan motivasi sendiri. Peserta didik dapat mengeksplor kemampuannya bersama teman-teman sekelompoknya, sehingga dapat menemukan sendiri jawaban yang diinginkan. Peserta didik kelihatan sangat aktif, antusias dan mengikutinya sesuai dengan langkah dalam LKS

\section{KESIMPULAN}

Berdasarkan pemaparan di atas dapat disimpulkan bahwa pembelajaran dengan model pembelajaran Discovery Learning layak dijadikan pembelajaran karena dapat meningkatkan kemampuan siswa dalam melakukan transfer pengetahuan, berpikir kritis, dan siswa menemukan sendiri jawabannya. Dengan penyusunan rencana pelaksanaan pembelajaran (RPP) secara sistematis dan cermat, pembelajaran dengan model pembelajaran Discovery Learning dalam pelaksanaannya dapat berjalan menyenangkan dan siswa akan antusias untuk mengikutinya.

\section{DAFTAR PUSTAKA}

Arends R. (2008) Learning to teach (Terjemahan Helly Prajitno dan Sri Mulyantini Sutjipto).

Yogyakarta: Pustaka Pelajar. (Buku asli diterbitkan tahun 2007)

Carin. A.A \& Sund.R.B. (1980). Teaching Modern Science. Ohio: Merril Publising 
Indarti, Sri. 2019. Investigasi Implementasi Model Discovery Learning Berbasis Pendekatan Saintifik Dalam Meningkatkan Aktivitas dan Hasil Belajar IPA. IJIS Edu: Indonesian Journal of Integrated Science Education 1(2): 100-104.

Kemendikbud. (2013). Materi Pelatihan Guru Implementasi Kurikulum 2013 SMP/MTs IPA, badan Pengembangan sumber daya Manusia pendidikan dan kebudayaan dan penjaminan Mutu Pendidikan

Khamidah, Ngulmi, Winarto Winarto, and Vita Ria Mustikasari. 2019. Discovery Learning: Penerapan dalam pembelajaran IPA berbantuan bahan ajar digital interaktif untuk meningkatkan prestasi belajar siswa. JIPVA (Jurnal Pendidikan IPA Veteran), 3(1): $87-99$.

Nuh, M. (2013). Lampiran Peraturan Menteri Pendidikan dan Kebudayaan RI, No. 65 tahun 2013. Tentang Standar Proses Pendidikan Dasar dan menengah

Nuh, M. (2013). Lampiran Peraturan Menteri Pendidikan dan Kebudayaan RI, No. 81A tahun 2013. Tentang Implementasi Kurikulum, pedoman Umum Pembelajaran

Prasetyo, Z.K. (2004). Kapita Selekta Pembelajaran Fisika. Jakarta: Universitas terbuka.

Setyawati, Endang. 2018. Upaya Peningkatan Hasil Belajar IPA Melalui Model Pembelajaran Discovery Learning Pada Peserta Didik. Ilmu Pendidikan: Jurnal Kajian Teori Dan Praktik Kependidikan 3(1): 50-59.

Simanjuntak, Mariati Purnama, Lasmaria Siregar, and Yenni Triana Lumbangaol. 2019. Penerapan Discovery Learning Terhadap Hasil Belajar Ipa Siswa Smp. Jurnal Inovasi Pembelajaran Fisika (INPAFI) 7(4): 25-33.

Slameto. (2013). Belajar dan Faktor-faktor yang mempengaruhi. Jakarta: Rineka Cipta.

Slavin, R E. (2011). Psikologi Pendidikan teori dan Praktek. (Terjemahan oleh Marianto Samosir). Jakarta: Indeks.( Buku asli diterbitkan tahun 2009)

Wahjudi, Eko. 2015. Penerapan discovery learning dalam pembelajaran IPA sebagai upaya untuk meningkatkan hasil belajar siswa Kelas IX-I di SMP Negeri 1 Kalianget.Jurnal Lensa, 5(1): 1-15.

Widiadnyana, I. Wayan, I. Wayan Sadia, and I. Wayan Suastra. Pengaruh model discovery learning terhadap pemahaman konsep IPA dan sikap ilmiah siswa SMP.Jurnal Pendidikan Dan Pembelajaran IPA Indonesia, 4(2). 